\title{
BHAKTI ANAK TERHADAP ORANG TUA (MENURUT AJARAN AGAMA HINDU)
}

\author{
Oleh \\ Heny Perbowosari \\ Dosen Institut Hindu Dharma Negeri Denpasar \\ henysari74@gmail.com
}

\begin{abstract}
ABSTRAK
Dalam pengenalan ajaran agama tidak luput dari peran orang tua yang merupakan pemberi dasar jiwa keagamaan, selain bertugas mendidik dan mengasuh kita. Dengan demikian sebenarnya tugas orang tua sangatlah berat, oleh karena kita sebagai anak yang berbakti harus menghormati orang tua sebagai imbalan dari apa yang telah dilakukan oleh orang tua kepada kita. Apabila kita selalu menghormati orang tua maka kita akan selalu mendapatkan kebahagiaan dalam kehidupan kita begitu juga sebaliknya apabila berdosa dan durhaka terhadap orang tua maka kesengsaraan yang akan kita peroleh. Hal ini tersirat dan tersurat dalam ajaran agama Hindu bahwa anak harus menghormati orang tua.
\end{abstract}

Agama merupakan kepercayaan, maka dengan agama pula kita akan merasa mempunyai suatu pegangan iman yang menambatkan kita pada satu pegangan yaitu Tuhan. Selain itu agama juga menyangkut kehidupan batin manusia. Oleh karena itu kesadaran agama dan pengalaman agama seseorang lebih menggambarkan sisi-sisi batin dalam kehidupan yang ada kaitannya dengan sesuatu yang sakral dan dunia gaib. Dengan adanya hal tersebut maka muncul adanya sikap keagamaan. Sikap keagamaan merupakan suatu keadaan yang ada dalam diri seseorang yang mendorong untuk melakukan sesuatu (berperilaku) sesuai dengan ketaatannya dalam beragama. Sikap keagamaan tersebut muncul karena adanya kepercayaan pada suatu agama.

Dalam hal ini kita sebagai umat Hindu percaya dengan adanya Tuhan, karena Tuhanlah yang menyebabkan kita ada di muka bumi ini, percaya adanya atman karena kehidupan ini ada karena adanya atman atau jiwa, tanpa adanya jiwa kita akan dapat hidup. Selanjutnya percaya adanya karmaphala, karena setiap perbuatan yang kita lakukan pasti akan mendatangkan hasil, baik itu perbuatan yang baik maupun yang buruk. Apabila perbuatan yang kita lakukan baik maka hasil yang kita dapatkan berupa kebahagiaan, sebaliknya apabila perbuatan yang kita lakukan buruk maka hasil yang kita dapatkan adalah penderitaan. Kemudian kita kita percaya adanya punarbhawa yang menyebabkan adanya kelahiran yang berulang-ulang. Adanya keterikatan seseorang akan sifat keakuannya akan menyebabkan adanya punarbhawa. Dengan adanya keserakahan, kemarahan, kejahatan seharusnya kita lenyapkan, dan yang terakhir kita 
percaya adanya moksa bahwa kita hidup di dunia ini berusaha untuk selalu melakukan perbuatan yang mulia guna mencapai kebahagiaan yang abadi.

Dalam pengenalan ajaran agama ini tidak luput dari peran orang tua yang merupakan pemberi dasar jiwa keagamaan, selain bertugas mendidik dan mengasuh kita. Dengan demikian sebenarnya tugas orang tua sangatlah berat, oleh karena kita sebagai anak yang berbakti harus menghormati orang tua sebagai imbalan dari apa yang telah dilakukan oleh orang tua kepada kita. Apabila kita selalu menghormati orang tua maka kita akan selalu mendapatkan kebahagiaan dalam kehidupan kita begitu juga sebaliknya apabila berdosa dan durhaka terhadap orang tua maka kesengsaraan yang akan kita peroleh. Maka dalam hal ini ada beberapa alasan mengapa kita sebagai umat Hindu harus menghormati kepada orang tuanya.

Beberapa ajaran agama Hindu yang menjadi landasan bagi orang Bali bahwa harus menghormati orang tua antara lain :

1. Dalam ajaran aguron-guron pada pustaka Sila Karma, mengandung nilai ajaran Catur Guru Bhakti untuk menuntun umat Hindu di dalam proses berguru menjadi seorang yang berguna serta memiliki budhi pekerti yang luhur. Disamping itu agar anak-anak menjadi seorang yang "Suputra", sebagai generasi yang bertanggung jawab nantinya kepada orang tua, keluarga, masyarakat dan negara. Di dalam ajaran Catur guru Bhakti, memiliki bagian-bagian yaitu :

\section{a. Bhakti terhadap Guru Rupaka}

Yang dimaksudkan dengan Guru Rupaka adalah orang tua dan para leluhur, yang telah memberikan tuntunan dan bimbingan kepada anak-anak secara terus menerus, melalui generasi ke generasi. Oleh sebab itu anak-anak sangat berhutang budhi kepada orang tua karena Beliau telah memberikan jalan kepada anak-anak bisa lahir (reinkarnasi) menjadi manusia. Dengan demikian anak-anak harus membayar hutang kepada orang tua dengan jalan berbhakti kepadanya, mau membantu kesulitan yang dihadapi orang tua, memberikan perhatian dan kasih sayang kepada orang tua, janganlah berbuat kasar kepada orang tua kepada orang tua seperti memukul, mengumpat, mencaci maki dan janganlah menceritakan kejelekan orang tua kepada orang lain.

b. Bhakti terhadap Guru Pengajian 
Yang dimaksud guru pengajian adalah guru di sekolah, tidak kalah utamanya dengan Guru Rupaka, karena guru di sekolahlah yang membuka kegelapan hati anak-anak berupa kebodohan. Tanpa beliau yang mengajarkan ilmu pengetahuan kepada anakanak maka anak-anak akan tetap menjadi bodoh. Oleh karena itu anak-anak berhutang budi kepada guru, dengan demikian anak-anak harus membayar hutang yang berupa mentaati peraturan-peraturan, rajin belajar, sayangilah gurumu seperti meyayangi orang tuamu.

\section{c. Bhakti terhadap Guru Wisesa}

Bhakti kepada Guru Wisesa artinya berbakti kepada pemerintah, karena pemerintah memberikan perlindungan terhadap rakyatnya. Dengan demikian kita harus berbakti kepada pemerintah berupa mentaati segala peraturan dan perundang-undangan yang ditetapkan pemerintah.

\section{d. Bhakti terhadap Guru Swadyaya (Ida Sang Hyang Widhi)}

Yang dimaksudkan dengan guru Swadyaya adalah berbakti kehadapan Sang Hyang Widhi karena Beliau memberikan tuntunan terhadap umat melalui wahyuNya, serta Beliau telah mencipatakan segalanya.

Dengan berlandaskan ajaran ini terutama ajaran Guru Rupaka maka bagi umat Hindu berbakti dan mnghormati orang tua adalah merupakan kewajiban yang harus dilakukan oleh seorang anak dengan cara selalu mendengarkan nasehatkan orang tua, tidak melawan orang tua, menjaga nama baik orang tua.

2. Adanya ajaran Dasa Nyama Brata yang mengajarkan tentang sepuluh pengendalian diri untuk mencapai kesempurnaan rohani dan kesejahteraan jasmani serta kesucian batin. Yama Brata merupakan peraturan kesusilaan yang merupakan pedoman hidup manusia untuk mencapai tujuan. Dalam Dasa Nyama Brata terdapat ajaran Anrsangsya yang artinya tidak mementingkan diri sendiri. Orang yang mementingkan diri sendiri hidup hanya untuk dirinya sendiri. Orang yang semacam ini tidak tahu bagaimana mengasihi dan menghormati orang lain. Oleh karena Anresangsya dapat juga diartikan harus hormat menghormati satu sama lain karena setiap orang mempunyai harga diri yang harus dihormati. Diantaranya yang dihormati dalam pergaulan hidup bersama para guru dan ibu bapa mendapat penghormatan yang istimewa. Ibu dan bapa adalah yang menyebabkan kita ada dan kita adalah hasil paduan kasih ibu bapa yang dibayar dengan mahal. Kita 
berhutang budi yang besar kepada mereka yang tak dapat dibayar dengan apapun juga. Menurut kitab Sarasamuccaya sloka 242 (dalam Sura, 1985) bahwa seorang bapak adalah :

- Sarirakrt, yaitu yang mengadakan tubuh,

- Pranadata, yaitu yanga memberikan hidup,

- Annadata, yaitu yang memberi makan.

Sedangkan ibu adalah sumber kasih sayang yang tiada taranya. Tidak ada kasih sayang yang melebihi kasih ibu. Dari ibulah mengalir kasih pertama meresapi tubuh kita. Pengertian yang demikian dinyatakan dalam sloka 244 kitab Sarasamuccaya. Maka itu hanya dengan bakti kita membalas segala yang diberikan orang tua. Kita tidak boleh berkhianat kepada orang tua.

3. Landasan agama bagi umat Hindu untuk selalu menghormati orang tua adalah ajaran Panca Nyama Brata yang mengajarkan pengendalian diri ke arah tingkat mental untuk mencapai kesempurnaan dan kesucian batin. Sesuai dengan pustaka suci "Wraspati Tattwa", Panca Nyama Brata terdiri dari lima bagian yaitu Akroda artinya tidak marah, Guru Susrusa artinya bakti kepada guru, Sauca artinya suci lahir batin, Aharalagawa artinya makan secukupnya, Apramada artinya tidak lalai. Di dalam menghormati seorang guru dalam hal ini orang tua kita mengarah kepada ajaran Guru Susrusa dimana mengajarkan tentang berbakti kepada guru. Yang pertama orang harus berbakti kepada guru rupaka yaitu orang tua (ibu dan bapak). Orang hendaknya sadar betapa besarnya pengorbanan dan kasih sayang orang tua yang telah dicurahkan kepada anaknya untuk memelihara dan mendidik. Orang yang durhaka kepada orang tuanya maka ia tidak akan selamat hidupnya di dunia maupun di akhirat kelak. Kedua, orang harus bakti terhadap guru pengajian yaitu guru yang mengajarkan berbagai ilmu pengetahuan dan mendidiknya sehingga menjadi manusia yang berguna. Seseorang yang tidak bakti terhadap guru pengajiannya tidak akan berhasil menuntut ilmu pengetahuan dengan sempurna. Ketiga orang harus bakti kepada guru wisesa, yaitu pemerintah yang mengayomi dan mengatur kehidupan bermasyarakat dan bernegara sehingga tertib dan damai. Selain itu orang harus bakti terhadap guru sejati yaitu Sanghyang Paramesti Guru, Tuhan Yang Maha Esa, karena beliaulah sumber segalanya di dunia ini. Gurususrusa menuntun orang kepada kesucian hati dan kearifan dalam berperilaku. 
4. Menurut ajaran agama Hindu, manusia tidak dapat hidup sendiri. Mereka saling memerlukan, saling membutuhkan satu dengan yang lain. Oleh karena itu mereka hidup berkelompok, bermasyarakat, berkeluarga. Mereka hidup saling ketergantungan sehingga mereka hidup berkelompok. Manusia hidup berkelompok dengan penuh saling pengertian dan kalau ada yang tidak mampu, mereka akan ditolong oleh mereka yang lebih mampu. Dengan demikian hidup manusia lebih berbahagia. Sebaliknya bila mereka tidak saling tolong menolong mereka akan hidup lebih menderita.

Rasa ketergantungan ini merupakan ciri khas hidup sebagai manusia, yang paling mendorong manusia hidup saling ketergantungan adalah karena adanya pengalaman mereka yang dikucilkan oleh orang lain. Selain itu seorang anak akan sedih apabila tidak mendapat kasih sayang dari ibu dan bapak. Dengan adanya rasa kasih sayang dan saling keterikatan itu, mereka akan merasa berdosa apabila tidak dapat membalas jasa orang yang telah menolong mereka.

Apabila kita mendapat bantuan dari orang lain maka kewajiban kita adalah membalas budi. Membalas budi merupakan perbuatan yang baik dan terpuji. Di dalam ajaran agama Hindu kita diajarkan tentang Tri rna artinya tiga macam hutang atau bisa diartikan tiga hutang yang wajiba dibayar atau dilaksanakan oleh umat manusia sebagai penganut agama Hindu, berdasarkan ketulusan hati dalam usaha untuk mencapai kebahagiaan hidup.

Tri Rna dapat dibagi menjadi tiga yaitu : 1) Dewa Rna berarti hutang jiwa kepada para Dewa sebagai manifestasi Sang Hyang Widhi yang bersifat Maha Pemurah dan Penyayang, 2) Rsi Rna adalah hutang buddhi berupa ilmu pengetahuan kepada para para Rsi, 3) Pitra Rna berarti hutang jasa pada pemeliharaan kepada para pitara/leluhur atau orang tua (Oka Netra, 1994).

Manusia sejak dilahirkan telah menerima kasih sayang dari orang tuanya, bahkan sejak semasih dalam kandungan telah mendapatkan perhatian dari orang tuanya. Kasih sayang yang diberikan oleh orang tuanya menyebabkan anak itu berhutang budi kepada orang tuanya. Oleh karena itu sebagai seorang anak harus menjaga apabila orang tuanya sudah tua dan tidak mampu melakukan pekerjaan. Seorang anak seharusnya juga selalu menjaga nama baik orang tuanya. Kita sebagai anak harus menjunjung tinggi serta menghormati orang tua. Apabila hal ini kita lakukan dengan sebaik-baiknya maka 
berkuranglah dosa-dosa kita. Pendeknya kewajiban kita adalah membalas budi agar kita tidak berdosa.

5. Hubungan Tri Rna dengan yajna sangat erat, apabila kita tinjau pengertian yajna merupakan sarana yang dapat digunakan untuk berhubungan dengan Sang Hyang Widhi beserta manifestasi-Nya. Oleh karena itu manusia seyogyanya melakukan persembahan secara tulus dan iklas kepada Beliau untuk dapat mencapai kebahagiaan. Dalam hal ini tujuan beryajna adalah untuk melepaskan diri manusia dari ikatan dosa, dan selanjutnya menuju kepada kebahagiaan yang abadi.

Dalam ajaran agama Hindu dikemukakan bahwa manusia lahir memiliki tiga hutang karma yang disebut Tri Rna. Ketiga hutang tersebut wajib dibayar dengan melaksanakan panca yajna yaitu :

1. Devarna menimbulkan pelaksanaan devayajna dan buthayajna

2. Rsirna menimbulkan pelaksanaan rsiyajna

3. Pitrarna menimbulkan pelaksanaan pitrayajna dan manusayajna (Sura, 1985).

Dalam kaitannya dengan menghormati orang tua maka disini kita harus melakukan pelaksanaan pitrayajna yang artinya korban yang dilaksanakan dengan hati yang tulus iklas kepada para leluhur (nenek moyang dan orang tua), karena tanpa adanya para leluhur (termasuk orang tua) kita tidak akan mungkin dapat hidup seperti sekarang ini. Kehidupan dan keselamatan yang kita peroleh adalah merupakan pemberian dan tuntunan dari leluhur kita.

\section{Daftar Pustaka}

1. Kadjeng, I Nyoman, dkk. 1988. Sarasamuccaya. Ditjen Bimas Hindu dan Budha Dep. Agama RI.

2. Oka Netra, Anak Agung Gde. 1994. Tuntunan Dasar Agama Hindu. Jakarta : PT. Hanuman Sakti.

3. Sura, I Gede. 1985. Pengendalian Diri Dan Etika Dalam Ajaran Agama Hindu. Jakarta : Ditjen Bimas Hindu dan Budha Dep. Agama RI. 